\title{
Can Insurance Firms Easily Exit from the Market? A Global Comparative Analysis of Regulatory Structures*
}

\author{
W. Jean Kwon, Hunsoo Kim and Soon-Jae Lee \\ School of Risk Management, St. John's University, 101 Murray St., Ste 503, U.S.A. \\ E-mail: kwonw@stjohns.edu
}

This paper deals with market exit issues in the insurance industry. It examines theoretical and practical aspects of exit regulation in insurance as well as internal and external factors that firms may use to select a market exit strategy. From comparing regulatory stringency and permitted forms of market exit in selected countries in Asia, Europe, and North America, the authors find several commonalities. That is, regulators tend to accentuate their responsibility for protecting policyholders' interests, be deeply involved in most exit processes, and prefer other forms of exit (e.g., buy-out of liabilities or a complete acquisition of business by another firm) than immediate dissolution of insurers. However, not all governments examined are ready to effectively deal with matters related to insurers' exits from the market. Some governments need better structured regulation and some transparency in market exit regulation.

The Geneva Papers (2005) 30, 268-284. doi:10.1057/palgrave.gpp.2510024

Keywords: exit regulation; liquidation; solvency; global insurance; run-off; M\&A

\section{Introduction}

All stakeholders in the insurance market, whether they are regulators, firm owners (principals), the management (agents) or policyholders, desire an insurance market that is sustainable and financially and operationally sound. The reason is obvious in that the likelihood of market distortion arising from insurer failure can be lower in such a market.

As a means to maintain a sound market environment, governments globally have in place numerous regulatory measures, which can be broadly classified into the following categories. First, entry into the market is not free in most insurance markets. In those markets, an applicant of insurance business is required to satisfy the minimum initial capital requirement for the class (line) of business it wishes to operate and show evidence that a fit-and-proper person will manage the firm. A successful applicant may further be subject to product and rate regulation especially for its operations in personal lines of insurance. Rules related to market entry requirements are fairly well prescribed in the insurance act, directly or through subordinating insurance regulations, in most countries.

\footnotetext{
* This research is in part funded by the Korea Research Foundation. The authors thank anonymous reviewers for valuable comments.
} 
Second, insurance supervisors put more emphasis than ever on their responsibility for monitoring financial and accounting activities of licensed insurance firms. As Eger ${ }^{1}$ contends, insolvency law entails, in part, that the supervisor to exercise an ex ante (before insolvency) sanction so that firm managers are deterred from "carelessly externalizing risks on the creditors." For this, supervisors commonly apply capital adequacy tests - particularly, risk-based capital or solvency margin that an insurer must meet to absorb shocks from engaging in underwriting and investment activities. For self-regulation, many insurance firms have in place a prudent corporate governance policy as well.

Finally, governments are increasingly aware of the importance of prudent exit regulation. Exit of any insurance firm from the market is of concern from a public policy viewpoint as well as from an economic activity viewpoint. ${ }^{2}$ With a rigid exit regulation in place, the government can protect the financial interest of insurance claimants of the firms exiting from the market (e.g., by transferring the insurer's money to insurance guarantee funds established in the jurisdiction). Indeed, the majority of insurance laws globally list the protection of policyholders' interests as a primary objective in insurance regulation and supervision. The laws prescribe that a firm withdrawing from a line of insurance business, or completely from the insurance market, is subject to the control of the regulatory authority throughout the entire exit process. The governing law can be the general bankruptcy code (as found in selected countries), the procedure stipulated in the insurance law (common), or both.

Not all countries, however, have established unequivocal policies governing insurer exit. The laws in several countries, particularly in the countries that had until recently a nationalized or closed insurance market, fail to elaborate transparently how they complete the protection of policyholders' and insurance claimants' interests or what process(es) incumbent insurers wishing to exit from the market must follow.

Let us further examine exit regulation. Several governments allow insurance firms to initiate a market exit process if they experience financial or operational difficulty. Two conditions are commonly attached to this voluntary liquidation: those insurers must acquire prior approval from the regulator of the exit process, and they must work closely with the regulator until the exit process is complete. It is assumed that without the involvement - often in the form of a direct control - of the regulator in the exit process, firm owners would attempt to maximize their own wealth, and the non-owner management of the firm would also attempt to increase their economic wealth as well as their values in the labour market.

The majority of governments examined in this paper do not allow voluntary liquidation. In fact, it is the regulators in all known markets that are authorized to take over the management control of insurance firms experiencing operational or financial difficulty. In several markets, for example, the regulatory authority can take over the control of an insurance firm when it has failed to comply with the minimum total

\footnotetext{
${ }^{1}$ Eger (2001).

${ }^{2}$ It can be argued that an exit barrier deters entry to the market. For instance, a scale economy that discourages new firms to enter a market may also work as a barrier for firms to leave the market. For further discussion, see Ilmakunnas and Topi (1999) and Europe Economics (2004).
} 
adjusted capital guideline in the country. ${ }^{3}$ Solvency II of the European Commission also suggests that a firm's failure to comply with the minimum thresholds gives rise to tough intervention by the regulatory authority, for example, freezing of assets or forced exit from the market. ${ }^{4}$

Government control of an insurer does not necessarily mean that the firm will be dissolved. More than often, such a firm undergoes a "rehabilitation" programme interchangeably a "receivership" programme - overseen by the regulator or its designee. Once successfully rehabilitated, it will be allowed to resume its normal operation; otherwise, it faces the risk of being involuntarily liquidated by the regulator. "Conservation of assets" is synonymous with liquidation in several jurisdictions.

Insurance firms exit markets for other reasons. ${ }^{5} \mathrm{~A}$ "merger" occurs when two firms dissolve their businesses and emerge into a single, newly incorporated entity. An "acquisition" takes place when a firm retains its name, thus its business licensure, and the target firm dissolves and becomes part of the acquiring firm. Firms may merge to generate some scale-scope effect, that is, an increase in efficiency, although the existing literature does not always support the presence of such efficiency. Insurers may acquire other firms for similar reasons. The target firm can be a financially or operationally sound firm whose owner wishes to sell it when the intrinsic value of the firm is estimated high. Or, it can be a firm under regulatory receivership. In many countries, all mergers and acquisitions of insurance firms are governed by the rules stipulated in the relevant act of the country.

Other internal and external forces affect an insurer's decision to exit a market. Exogenously, a change in government policy, prevailing economic conditions, market competition, a development in the legal liability environment, a man-made or natural catastrophe, and the expansion of consumerism activities, among others, can cause an increase in the insurer's cost of operation. Firm-specific forces may include, among others, firm size, ownership structure, operating and managerial expertise, and claimspaying ability. Indeed, these forces have resulted in numerous firms exiting from the insurance market. Table 1 enumerates market exit patterns in selected countries.

\section{Regulatory and managerial conflict in market exit regulation}

Regulation can be costly. Regulation can debar a market from being contestable. A contestable market should allow firms to enter free of cost and, on exiting from the market, to liquidate their capital without any loss or completely remove it to an alternative use. ${ }^{6}$ In the insurance market, firms incur a sunk cost of operation: to enter

\footnotetext{
${ }^{3}$ Broadly defined, the total adjusted capital - whether used for risk-based capital or solvency margin calculations - refers to the policyholders' surplus of an insurance firm adjusted for loss reserve excess (or deficiency) and discount for time value of money.

${ }^{4}$ European Commission (2002).

${ }^{5}$ Insurance firms may change their country (state) of domicile or name, or transform a branch into a subsidiary. Redomestication, localization and name change do not carry the managerial intent to exit a market, and are not examined in this paper.

${ }^{6}$ Baumol et al. (1982).
} 
W. Jean Kwon et al. Exit Regulation

Table 1 Market exit forms in the global insurance market (1998-2003)

\begin{tabular}{|c|c|c|c|c|c|c|c|c|}
\hline \multirow[t]{2}{*}{ Country } & \multicolumn{2}{|c|}{ Voluntary } & \multicolumn{2}{|c|}{ Involuntary } & \multicolumn{3}{|c|}{ Ownership Changes } & \multirow[t]{2}{*}{ Other } \\
\hline & $\begin{array}{l}\text { Liquidation } \\
\text { and in-kind }\end{array}$ & Other & Liquidation & Other & Merger & Acquisition & $\begin{array}{l}\text { Name } \\
\text { change }\end{array}$ & \\
\hline American Samoa & & & & & & & 1 & \\
\hline Australia & 3 & & & & 1 & 3 & 16 & 1 \\
\hline Austria & & & & & & & 3 & \\
\hline Bahamas & & & & & & & 2 & \\
\hline Bahrain & & & & & 2 & & 1 & \\
\hline Barbados & 22 & 7 & & & & 1 & 2 & \\
\hline Belgium & & & & & 12 & 5 & 15 & 3 \\
\hline Bermuda & 19 & 1 & & & 3 & 1 & 34 & 3 \\
\hline Brazil & & & & & 1 & & 18 & 3 \\
\hline Canada & 9 & 2 & 1 & & 11 & 10 & 51 & 25 \\
\hline Cayman Islands & 5 & 5 & & & 1 & & 3 & \\
\hline Colombia & & & & & & & 2 & \\
\hline Czech Republic & & & & & & & 4 & \\
\hline Denmark & & & & & & & 21 & 3 \\
\hline Dominican Rep. & & & & & & & 1 & \\
\hline Finland & & & & & & 2 & 13 & \\
\hline France & 1 & 2 & & & 11 & 23 & 58 & 16 \\
\hline Germany & 2 & & & & 24 & 37 & 121 & 2 \\
\hline Greece & & & & & 3 & & & \\
\hline Guernsey Islands & 10 & & & & & 1 & 1 & \\
\hline Hong Kong & & & & & & & 10 & \\
\hline Hungary & & & & & & & 1 & \\
\hline Indonesia & & & & & & & 4 & \\
\hline Ireland & 2 & 4 & & & & 2 & 32 & \\
\hline Italy & 1 & & 3 & & & 25 & 43 & 4 \\
\hline Japan & 1 & 1 & 2 & & 8 & 1 & 17 & 1 \\
\hline Jordan & 1 & & & & & & & \\
\hline Korea $^{\mathrm{b}}$ & & & & & 1 & & 2 & \\
\hline Lithuania & & & & & & & 2 & \\
\hline Luxembourg & & & & & & & 1 & \\
\hline Malaysia & & & & & & 2 & 4 & \\
\hline Mexico & & & & & & & 5 & 1 \\
\hline Netherlands & 2 & & & & 1 & 2 & 31 & 1 \\
\hline New Zealand & & 1 & & & & 1 & 14 & \\
\hline Norway & 1 & & & & 2 & & 3 & 4 \\
\hline Oman & & & & & & & 1 & \\
\hline Panama & 1 & & & & & 1 & & \\
\hline Poland & & & & & & & 3 & \\
\hline Portugal & & & & & & 7 & 1 & 2 \\
\hline Singapore & 1 & & & & & & 5 & \\
\hline Slovakia & & & & & & & 1 & \\
\hline South Africa & & & & & & & 6 & 2 \\
\hline Spain & 9 & & & & 3 & 6 & 20 & 1 \\
\hline Sweden & 2 & 2 & & & 1 & & 10 & 1 \\
\hline Switzerland & & & & & 3 & 4 & 11 & \\
\hline Turkey & & & & & & & 2 & \\
\hline United Kingdom & 33 & 12 & & & 9 & 2 & 188 & 16 \\
\hline United States $^{\mathrm{c}}$ & 95 & 2 & 102 & 56 & 9 & 344 & 620 & 137 \\
\hline
\end{tabular}


Table 1 (continued)

\begin{tabular}{|c|c|c|c|c|c|c|c|c|}
\hline \multirow[t]{2}{*}{ Country } & \multicolumn{2}{|c|}{ Voluntary } & \multicolumn{2}{|c|}{ Involuntary } & \multicolumn{3}{|c|}{ Ownership Changes } & Other \\
\hline & $\begin{array}{l}\text { Liquidation } \\
\text { and in-kind }\end{array}$ & Other & Liquidation & Other & Merger & Acquisition & $\begin{array}{l}\text { Name } \\
\text { change }\end{array}$ & \\
\hline Virgin Islands (U.K.) & 5 & & & & & & 3 & \\
\hline Total & 320 & 41 & 210 & 57 & 115 & 824 & 2027 & 363 \\
\hline
\end{tabular}

Source: A.M. Best Reports: Property \& Casualty; Life \& Health; and International (Database as of June 2004).

${ }^{a}$ Includes run-offs and discontinued operation.

${ }^{\mathrm{b}} \mathrm{See}$ the discussion about Korea in the paper for correct information.

${ }^{c}$ From different source, thus U.S. figures not perfectly comparable to other countries.

a market and to exit from the market. Whether the cost - for example, capital outlay that cannot be recovered without substantial delay - is relatively lower than that of manufacturers matters little, because it is irrecoverable. ${ }^{7}$

Firms may exit a market when they fail to earn a sustainable rate of return. Firms at a declining stage of business life cycle may form an exit strategy instead of, as Resnick ${ }^{8}$ argues, making a further capital commitment to the business. Firm owners and their agents have every incentive to recover their investment capital as much as possible on completing the exit. ${ }^{9}$ Hence, exit regulation in insurance can give rise to conflict between the management (i.e., wealth maximization motive) and the regulator (i.e., public policy motive).

Everything being equal, the management of a firm would have a faster access than all other stakeholders - including the regulator - to signals indicating financial or operational difficulty of the firm. Jensen and Meckling ${ }^{10}$ support this with an agency theory, which shows that the manager has superior information to the shareholders and policyholders of the distressed insurance firm. Whether the management will respond faster than, say, the regulator, to the signals depends on the strength of the wealth motive of the management and the expected net worth of the firm. ${ }^{11}$ Generally,

${ }^{7}$ Contestability theory also suggests that if exit from a market were costless, firms entering the market would not fear of price reductions by incumbent firms.

${ }^{8}$ Resnick (1998).

${ }^{9}$ Peach (1998).

${ }^{10}$ Jensen and Meckling (1976).

${ }^{11}$ For foreign direct investment, Nees (1981) and Boddewyn (1983) argue that the fact that a firm is exiting from an overseas market would often signal a failure where the investors play a waiting game. They may decide to withdraw from the market only after having tried to revive the firm, thus the return of their investment, and only with a support of the top management and others. See also Matthyssens and Pauwels (2000). 
the weaker the wealth motive of the management or the smaller the net worth of the firm, the less likely it is that the management will take prompt action. A slow response by the management to the signals may lead to the regulator taking over the control of the firm.

Depending on who initiates the exit process, available forms of exit from the market vary. When a firm initiates it, it can choose from reorganization, merger, being a target for acquisition, or voluntary liquidation. Karakaya ${ }^{12}$ argues that voluntary liquidation helps shareholders salvage their investment in the liquidated firm. By comparison, regulator's choices of action are as follows: implementing a rehabilitation programme, making the firm available for acquisition, or involuntarily liquidating the firm.

The conflict resulting from this type of information asymmetry is less likely to arise when the law bars voluntary liquidation. However, such a measure does not guarantee that the regulator will effectively assist insurance firms under distress. Besides, whether or not voluntary liquidation is permitted may matter little in a market where the regulator's decision reflects more the interest of the industry than that of the consumer, that is, when evidence of capture theory of regulation is found. Similarly, political traits and the philosophy of the regulatory authority, let alone the operating efficiency of the authority, can make a difference in the speed and cost of the exit process from the market.

Another important issue in exit regulation is valuation of outstanding insurance obligations. Generally, valuation of unearned premiums tends to be direct, but valuation of loss reserves - including incurred-but-not-reported (IBNR) losses - can be very complicated, especially for long-tail or volatile lines of business. In the case of a merger or acquisition involving a financially and operationally sound firm, measurement of the franchise value of insurance business becomes another issue.

The size of liabilities of insurers and reinsurers in run-off - business of firms being liquidated or residual insurance obligations in the lines and territories that other firms cease to operate - continues to grow, now amounting to US\$285 billion globally. ${ }^{13}$ Seventy-one per cent of the estimate is related to insurers' liabilities, and the rest to reinsurers'. The majority of the run-off business is concentrated in Bermuda, France, Germany, Japan, the United Kingdom, and the United States. The latter holds the largest share.

A KPMG survey ${ }^{14}$ reveals that the total run-off liabilities in the London market were $£ 33$ billion, or around 28 per cent of the U.K. non-life insurance business. ${ }^{15}$ This translates into around $£ 4.3$ billion of policyholders' surplus tied up with run-off nonlife insurance firms in the market. Another survey by $\mathrm{KPMG}^{16}$ for life insurance shows run-off liabilities amounting to $£ 118$ billion, or 14 per cent of liabilities of all

12 Karakaya (2000).

13 Association of Run-off Companies (2003).

${ }^{14}$ KPMG International (2003).

${ }^{15}$ This figure excludes liabilities of firms regulated by other EU states and businesses written at Lloyd's of London.

${ }^{16}$ KPMG International (2004). 
U.K. life insurance firms. This leads to some $£ 6$ billion of policyholders' surplus tied up with run-off life insurance firms in the London market.

A well-structured market exit guideline is indicative of a transparent regulatory environment and helps the market attract more firms and improve its operational stability. Despite the importance of the role of exit regulation, only a few studies have examined this field. In fact, numerous studies focus more on market participant's entry and market entry barriers ${ }^{17}$ or market exits in a competitive market in general. ${ }^{18}$ Research in insurance is still rare, and existing studies examine a particular form of exit. For example, BarNiv and Hathorn ${ }^{19}$ compared insurers exiting through M\&A with those staying in the market to examined why and how firms exit from insurance markets.

The conflict between the regulator and firm owners (thus their agents) warrants examination. In this paper, the authors scrutinize insurance acts in selected countries in Asia, Europe, and North America to investigate how exit regulations are structured in those countries, and suggest means to improve exit regulations in those countries.

\section{Comparative analysis of market exit regulation ${ }^{20}$}

Insurance acts in many countries share several commonalities. Promotion of public awareness of insurance benefits, protection of policyholders' and claimants' rights, imposition of minimum capital and human resources qualifications are some of the examples. Key supra-governmental agencies in the financial services sector, too, share such commonalities. The International Association of Insurance Supervisors (IAIS) has adopted core principles covering from capital adequacy to market conduct to prudential requirements. The New Basel Capital Accord, which applies to the banking industry, also has minimum capital requirements, supervisory review of capital adequacy, and public disclosure as its three pillars. $^{21}$

One of the IAIS principles (ICP 16) deals specifically with insurer's winding-up and exit from the market. The principle states that regulatory authorities need to clearly define insolvency, establish the criteria and procedure for dealing with insolvency, and give priority to the protection of policyholders. ${ }^{22}$ Merger with a healthier insurance firm and a complete closure of the business are two of the means the IAIS suggests that troubled firms may use. In the remaining part of this section, the authors compare regulatory structures dealing with insurer exit in selected countries.

\footnotetext{
${ }^{17}$ For example, Bain (1956); Baumol et al. (1982); Bernheim (1984).

${ }^{18}$ For example, Resnick (1998); Peach (1998).

19 BarNiv and Hathorn (1997).

${ }^{20}$ The discussion in this section is based on authors' compilation of insurance acts in various countries. As insurance markets, in a country or globally, continue to develop, part of the discussion could be based on non-current regulatory guidelines.

${ }^{21}$ Basel Committee on Banking Supervision (2003).

${ }^{22}$ IAIS (2003).
} 
Asia

Several Asian countries maintain very stringent market exit guidelines. The 2003 Insurance Law of P.R. China, ${ }^{23}$ for instance, prescribes that division, merger, or any cause for dissolution of an insurance firm is subject to the approval of the financial supervisor, for example, the insurance authority, and that a liquidation task force (not defined in the act) carries out the process. It also prescribes that the People's Court determines (financial) insolvency of insurance firms. However, it does not permit dissolution of life insurance firms: they are allowed only to enter into arrangement with other insurance firms for the transfer of their life insurance contracts and technical reserves. If a defunct life firm fails to make such an arrangement, the China Insurance Regulatory Commission, may designate certain insurance firms to take over the insurance liability and reserves of the defunct.

In Hong Kong, an insurance firm that has failed to meet the legally required solvency margin is deemed unable to pay its debts. Such a firm can be liquidated. The Insurance Ordinance of Hong Kong, SAR, details how the insurance funds of a bankrupt firm should be valued and allocated to the interested parties of each fund and of the firm. The ordinance states that the insurance authority or a group of 10 policyholders may file a petition for bankruptcy of an insurance firm to the Court of First Instance. The court makes a decision based on the Companies Ordinance of the special administration region. The insurance act also states that voluntary liquidation of long-term (insurance) business is not allowed unless the Court of First Instance rules otherwise. ${ }^{24}$ When a firm in the long-term business becomes insolvent, the liquidator (e.g., the insurance authority) carries on his/her duty with a view of transferring the liabilities of the defunct as a growing concern to another insurance firm. The latter firm can be an existing firm or newly incorporated.

In Japan, the Insurance Business Law of 1996 includes provisions dealing with portfolio transfer, dissolution, and liquidation of insurance business. The law implies government's preference, among the market exit choices, to a voluntary "comprehensive" transfer of the insurance portfolio from the distressed to a sound insurer. When a distressed firm fails to secure a buyer within a reasonable period, the prime minister may subject the firm to a rehabilitation programme administered by the Financial Services Agency of Japan. ${ }^{25}$ Concurrently, the prime minister may seek a candidate firm, or a group of firms, for the "comprehensive" transfer.

When no firm appears to be interested in accepting the bulk transfer or acquiring the firm and when the financial position of the distressed insurer fails to improve, the prime minister may finally declare bankruptcy of the firm and order creation of a Policyholders' Protection Corporation. The corporation assumes, directly or through a subsidiary it creates, the insurance contracts of the bankrupt firm. All licensed

\footnotetext{
23 The Insurance Law of P.R. China (2003).

${ }^{24}$ Part 2 of the First Schedule of the ordinance defines "long-term business" as insurance business in life and annuity (including tontines), and permanent health, and retirement scheme arrangements. The ordinance also defines it as insurance products other than those classified as general insurance business.

25 The General Insurance Association of Japan (2003).
} 
insurance firms in that class of business participate by law in the corporation. The law permits creation of separate corporations for life and non-life businesses.

The Asian economic crisis in the late 1990s changed the map of the Korean insurance industry. The then government concluded that, of 50 insurance firms operating in 1997, 18 life and four non-life firms were under extreme financial distress. This led to the exit of five life companies through liability transfer to other firms, of five more life companies through acquisition by other firms, rehabilitation of one firm, and a merger between two non-life insurance firms by year-end 2000. The government used public funds to fill the gap between the liabilities and liquidated assets of those financially troubled firms, a practice that is unlikely to be repeated. The government amended in 2002 the Act on Structural Improvement of Financial Industries. This act provides guidelines for mergers between financial firms and means of exit from the market, for example, reorganization or liquidation of financially distressed firms.

In Malaysia, a local insurance firm may voluntarily liquidate its operations by transferring the whole of its business to another firm. The Insurance Act of 1996 (amended in 1999) of Malaysia, in conjunction with the Companies Act of 1965, bars any other forms of voluntary liquidation. The regulator, Bank Negara, may initiate a winding-up process of any financially trouble insurance firm by submitting a petition to court. In all cases of liquidation, the value of the firm's assets and liabilities must be ascertained on the basis set by the regulator. The Malaysian bankruptcy law does not apply to insurer bankruptcy or valuation of insurance liabilities.

The Malaysian insurance act elucidates the priority given to the policyholders and claimants of a bankrupt firm over general creditors and debt holders. This application is insurance fund specific. Put differently, only if the assets of a fund exceed the liabilities can the excess be used to meet any deficiency of another fund or funds of the firm.

Similarly, no other forms of voluntary liquidation other than a complete transfer of insurance liabilities to another firm are allowed in Pakistan. As per involuntary liquidation, Pakistan Insurance Ordinance of 2000 prescribes that only the insurance authority, the Securities Exchange Commission of Pakistan, may initiate the process by filing a petition to court. Two unique provisions can be found in the ordinance. First, when deemed necessary (i.e., the liabilities being greater than the assets of a defunct insurer), the court may order a reduction of life insurance benefits of the policyholders with the insolvent insurer. Second, the ordinance contains a provision dealing with winding up of an insurance firm, which has assumed the liabilities of another bankrupt firm. It states that when both firms are simultaneously liquidated, a single liquidator may work for both cases on an equitable basis.

In Singapore, the Monetary Authority of Singapore becomes a party - according to the Companies Act - of any proceedings that are to dissolve insurance firms whether or not such dissolution is based on financial difficulty of the firms. In the case of dissolution due to insolvency, the liquidator uses a basis approved by the court - not by the Companies Act - for the valuation of the liabilities of the firm. The basis is not defined in the insurance law. As in all other countries examined, the insurance authority in Singapore may petition for involuntary winding up of insurance business. The petition can be for complete dissolution of insurance operation or partial winding 
up of a class of insurance business (e.g., cessation of operation in one class of business while leaving the other class of the firm intact).

Transfer of insurance business to another on-shore insurance firm is a permitted form of market exit in Singapore. However, the Insurance Act of 2000 (amended in 2003) states that a mutual firm (a cooperative) may transfer its business only to another mutual firm. The law sets priority among creditors of an insolvent firm such that the assets of the firm must be available first to meet the liabilities of policyholders - whether they are holders of Singapore policies or offshore policies. The Policy Owners' Protection Fund of the country guarantees the full amount of liabilities of insolvent firms for compulsory insurance and 90 per cent of liabilities for life business. Both exclude liabilities arising from the contracts of reinsurance.

The Thai regulator, the insurance department of the Ministry of Commerce, may revoke the license of an insurance firm that has failed to meet solvency margin requirements. The firm - as prescribed in the Nonlife Insurance Act of $1992-$ must be resolved from the date of revocation and begin a liquidation process. This regulation applies to life business as well. In Thailand, insurance firms may voluntarily liquidate business, provided that they notify the authority at least 3 months prior to the actual cessation of business. Similarly, they may merge with any other limited companies, private or public, subject to approval from the regulatory authority. The merged firm must apply for new licensure within the period stipulated in the act.

When experiencing severe financial distress (e.g., having failed to meet the minimum solvency margin), an insurance firm in Vietnam may take one of the following two options. First, it may attempt to reorganize its management and operations according to a plan approved by the Ministry of Finance. If the firm fails to successfully complete the reorganization programme, the ministry may establish a board of solvency to take over the control of the programme. Second, it may attempt to voluntarily liquidate by transferring its insurance portfolios to another firm. This exit option is subject to a successful submission of evidence to the ministry that the firm is capable of paying all outstanding debts. If the firm fails to execute either option within a specified period, the ministry may declare the firm insolvent and appoint other insurance firms to take over the portfolios of the insolvent firm. The Insurance Law of 2000 of Vietnam permits merger or consolidation of two insurance firms or division of a single firm into two firms.

Legal procedures dealing with market exit can also be found in other Asian countries. For example, Macau Insurance Companies Ordinance of 1997 includes a provision that winding up of insurance business shall be dealt with in conjunction with the General Companies Law and the relevant articles in the ordinance.

In the United Arab Emirates, insurance firms may transfer part of, or the entire, insurance obligations to another firm, provided that the firm has secured approval from the Ministry of Finance. When filing for such a petition, the firm must submit proof showing that it has met all insurance obligations. The Federal Law (Insurance) also contains a similar provision related to a merger of two insurance firms.

The insurance law of Iran is very simple and prescribes primarily the basic elements of insurance contracts, insurance business, and insurer obligations. As per distribution of assets of insolvent insurers, the law merely states that insureds have priority over 
other creditors, life insurance claims over claims in other classes, and premium debts (i.e., unearned premiums) over all other debts.

\section{Europe}

The European Commission issued the Directive on the Reorganization and Winding up of Insurance Undertakings in $2001 .{ }^{26}$ It discusses matters related to market exits in insurance - exits resulting from insolvency as well as voluntary and compulsory liquidation. It also discusses how member states should coordinate matters concerning insurer reorganization and liquidation.

This directive does not impose harmonized measures for reorganization or procedures for liquidation. It leaves this authority with each home member state. Neither does it govern the effects of the reorganization measures and wind-up procedures concerning third countries. ${ }^{27}$ However, it introduces two important principles. The principle of unity states that only the competent authority of the home member state should be empowered to make decisions on wind-up procedures. The directive notes that a competent authority responsible for rehabilitating or winding up of an insurance firm can be different from the government body in charge of supervising the insurance market. The principle of universality recommends that all the assets and liabilities of insurance undertakings be considered in the wind-up procedures. $^{28}$

The directive places "utmost importance" on the protection of the "direct" rights of policyholders, beneficiaries, and claimants in the wind-up process. This can be interpreted in two ways. First, policyholders, beneficiaries, and claimants of an insurance firm in liquidation will have priority over other creditors. Second, those "direct" creditors may have priority over firms having reinsurance arrangements with the firm. This EU directive became the backbone of the U.K. Regulations (Reorganization and Winding Up) of 2003. ${ }^{29}$

In line with this directive, the insurance acts of EU member states offer specific guidelines to firms wishing to exit insurance markets. The Insurance Act of 1995 of Austria, for example, states that liquidation of insurance business is not subject to the Bankruptcy Code of Austria and that an insurer wishing to exit a market must notify the authority of insolvency or excessive indebtedness of its insurance obligations. The actual liquidation process is instituted only after the Austrian Financial Market Authority has completed filing of the bankruptcy proceeding, which will be

${ }^{26}$ (Directive 2001/17/EC). EC's First Council Directive issued in 1973 and all subsequent amendment directives deal with, among others, a single authorization related to market entry. However, they do not contain any coordination rules related to market exit in insurance.

${ }^{27}$ In the case of reorganization or liquidation of a branch of an insurance firm in a third country, the member state where the branch is located is deemed the home state. If a firm residing outside the EU has more than one branch, each branch is treated independently in determining the home member state, subsequently a reorganization or liquidation process.

${ }^{28}$ Every (financially solvent) insurance firm in an EU member state always maintains that the total value of its assets be no less than the value of technical provisions.

${ }^{29}$ KPMG International (2003). 
immediately granted by the court. A trustee appointed by the court is responsible for administering the actual process. The act additionally requires that if the insurance firm is subject to a bankruptcy proceeding, it must submit a list of Deckungsstock (covered assets reflecting liability reserves).

The Consolidated Insurance Business Act of 2003 in Denmark, another EU member state, lays down rules related to the entire transfer of insurance business. The transfer is subject to approval of the regulator, Finanstilsynet, and results in an automatic winding up of the firm. Dissolution of insurance business in any form other than merger is subject to regulatory approval. Besides, a life insurer wishing to dissolve its business must secure consent from each and every policyholder unless the dissolution is through a bulk transfer of its insurance liabilities. Other special rules are found in the law. The government may exercise its power to involuntarily subject a firm's business - particularly life business - to the control of a government trustee, or to liquidate firms under extreme financial distress.

The Slovenian government permits insurance firms to transfer their insurance liabilities to other firms with a prior approval from the regulator; consent of their policyholders is not a required element. As in most other countries, only the regulatory authority can initiate rehabilitation or bankruptcy proceedings. The regulations governing the bankruptcy of commercial firms also apply to insurance firms.

In Norway, a non-EU member state, insurance firms wishing to merge or de-merge must secure approval of their resolutions from the King. Firms wishing to wind up or dissolve their businesses are subject to the same requirement. Once approval is granted, the regulatory authority, Kredittilsynet, functioning as a probate court, administers the process. Likewise, insurance firms, including mutual firms, in Norway may request voluntary restructuring or permanent discontinuance of their businesses.

\section{North America}

Canada maintains a dual regulatory system. The federal agency, the Office of the Superintendent of Financial Institutions, supervises federally chartered - multiprovince operating - insurance firms and branches of foreign firms. Provincial agencies oversee operational and financial soundness of locally incorporated firms, which in aggregate comprise about one-fourth of all firms in Canada. The federal government administers the Insurance Companies Act of Canada, which deals with liquidations and dissolutions not governed by the Winding up and Restructuring Act of Canada. ${ }^{30}$ Provincial authorities administer the insurance law of the province, which deals with insolvency matters not subject to the Companies Act of the province.

Insurance firms in Canada may dissolve voluntarily. In Newfoundland and Labrador, for example, an insurance firm may pass a resolution internally to wind up its business, provided that it notifies the minister of the decision. In the case of a society or mutual firm, the insurer must seek consent from the provincial minister for

${ }^{30}$ When applied to insurance business, the Winding up and Restructuring Act of Canada deals with insurer insolvency arising mainly out of its inability to meet its liabilities or defraud of creditors. This applies to cases when an insurance firm and its assets are under the control of the regulatory authority. 
its voluntary liquidation. The ministerial power to involuntarily wind up an insurance firm may vary. In Manitoba, for instance, the superintendent may seek a court order against cases related to non-continuance of business or violation of the licensure guideline by a provincial insurance firm. The superintendent may take possession of an insurance firm for up to 16 days. If the firm's financial condition does not improve, it may even apply to the attorney general to wind up the firm. ${ }^{31}$

In the United States, insurance business is exempted from federal regulation, and is thus not subject to federal bankruptcy proceedings. Nor does the U.S. Bankruptcy Code of 1978 protect insurance firms in the country. The code states that an insurance firm - whether domestic or alien - cannot be a debtor under Chapter 11 (reorganization) or Chapter 7 (liquidation). The U.S. Bankruptcy Code does not apply to banks, credit unions, loan associations, or railroad businesses as well.

Each U.S. state has its own act that governs, among others, exit of licensed insurance firms in the state. Exit regulation guidelines in U.S. states are based mainly on the Rehabilitation and Liquidation Model Act of the National Association of the Insurance Commissioners (NAIC). This NAIC model act prescribes that only the insurance commissioner of the domiciliary state of an insurer may bring delinquency proceeding against the insurer, and that the court will hear proceedings commenced only by the commissioner. ${ }^{32}$ The model act also deals with grounds for rehabilitation or liquidation, liquidation proceeding, and rehabilitation programs of domestic, foreign, and alien insurers. ${ }^{33}$

Under this state regulatory scheme, insurers wishing to exit the (state) market must communicate with the regulator in their domiciliary states. An exiting firm will then be subject to the regulatory guidelines and, when necessary, the general bankruptcy procedures of the state. As per merger between insurance firms or acquisition of an insurance firm, the state insurance department, in conjunction with the state court, plays a similar role. Risk-based capital (RBC) guidelines, particularly authorized and mandatory control level RBCs, offer the basis for regulator's intervention or control insurer operations.

Let us use the New York regulation to further describe exit regulation in the United States. Like the laws in other U.S. states, the New York law prescribes matters of rehabilitation, liquidation, dissolution, and conservation of insurance firms. First of all, the state law lists 15 grounds each as a possible cause for the regulator to initiate a rehabilitation process against insurance firms. Insolvency, impairment of capital, and hazardous condition (whether financial or dishonesty-related) are three such grounds. Bulk transfer of insurance business to another insurance firm without approval of the regulator is another.

The regulatory authority "may" commence an exit process when an insurer voluntarily liquidates or dissolves, or attempts to do so. In other words, the authority may let the firm liquidate without intervention. Regarding this potential regulatory

31 IMF (2000).

32 The NAIC act defines "delinquency proceeding" as "any proceeding instituted against an insurer for the purpose of liquidating, rehabilitating or conserving such insurer, and any summary proceeding...."

${ }^{33}$ In the U.S. insurance industry, a foreign firm commonly refers to an insurer incorporated in another U.S. state, and an alien firm incorporated outside the United States. 
inconsistency, Dunham and Warrick ${ }^{34}$ show that the benefits from non-intervention include low legal cost for dissolution and speedy payments of (insurance) benefits. The counterpart cost can be the danger that the firm may be viewed as being liquidated preferentially or its officers and trustees may act improperly.

In New York, the regulator is responsible for creating a rehabilitation plan. The plan may include a scheme that permits the subjected firm to be available for sale to investors. If the firm is a mutual entity, the firm cannot be sold but may be permitted to issue surplus notes to investors, who will then control the firm's operation. Restoration to normal business operation can be granted when the firm has a sufficient (impaired) capital such that the daily fluctuation in the market value of the firm's assets does not likely make the firm (technically) insolvent. When the firm fails to meet this condition, it can eventually be liquidated and dissolved unless the firm successfully proves in court that, for instance, the rehabilitation period should be extended. Significant variations in the length of rehabilitation programmes - some over 15 years - exist across U.S. states.

The New York regulator may also use the grounds for rehabilitation to apply for a liquidation order from court. Whether an insurer has been subject to a rehabilitation programme is not a necessary condition for the court filing. However, the court "must" enforce the liquidation order once the firm has been found to violate any of the grounds for liquidation. An order of liquidation of an insurer terminates the existence of the firm. The order also fixes the rights and liabilities of the firm as of the date of liquidation, and allows a liquidator to take over control of the firm. The liquidation process ends only after all the assets of the firm have been marshalled and distributed to the claimants. Claimants of insurance matters, followed by the relevant fund of the state (e.g., Property-Casualty Insurance Security Fund), have priority over other claimants.

The New York regulator may conserve the assets of alien insurers for the purpose of liquidating them. As shown in Table 2, the scope of grounds for liquidation varies depending on the place of incorporation. ${ }^{35}$ Of the domestic, foreign, and alien firms in New York, domestic firms are subject to the broadest scope of the regulation and alien firms to the narrowest.

In New York, any merger or acquisition of control of a domestic insurance firm is subject to regulatory approval. Bulk reinsurance of insurance business of a domestic firm or conversion (mutualization or demutualization) of a firm is also subject to approval by the state regulator. An authorized merger or acquisition agreement becomes effective on the date or a specific date stipulated in the agreement once it is filed in the county office where the principal office is located.

Variations to the NAIC model act as well as differences with the New York law can be found in other states. In Pennsylvania, the Office of Liquidations, Rehabilitations and Special Funds plays the role of rehabilitator or liquidator. The Pennsylvanian regulator can issue an order of supervision that requires an insurer to take a specific

\footnotetext{
${ }^{34}$ Dunham and Warrick (2003).

${ }^{35}$ The grounds for liquidation in the New York law are slightly different from those in the NAIC model act.
} 
Table 2 Grounds for rehabilitation (liquidation, conservation) based on place of incorporation New York Insurance Law

\begin{tabular}{|c|c|c|}
\hline Grounds & $\begin{array}{c}\text { Domestic firm } \\
\text { (13 grounds) }\end{array}$ & $\begin{array}{l}\text { Foreign firm } \\
\text { (11 grounds) }\end{array}$ \\
\hline
\end{tabular}

(a) [Financial] insolvency

(b) Refusal to submit records

(c) Impairment of capital or surplus

(d) Bulk transfer [without prior approval]

(e) Hazardous [financial or ethical] conditions

(f) Violation of charter or law [of New York]

(g) Refusal of examination

(h) Failure of incorporation or authorization requirements

(i) Ceases doing business [for more than one year]

(j) Voluntary liquidation

(k) Appointment of receiver

(1) Consent [to rehabilitation by a majority of directors]

(m) Failure to obtain license

(n) Failure to remove officer or director

(o) Authorized or mandatory [RBC] control level event ${ }^{\text {a }}$

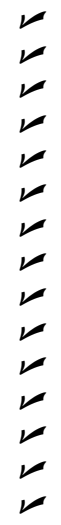

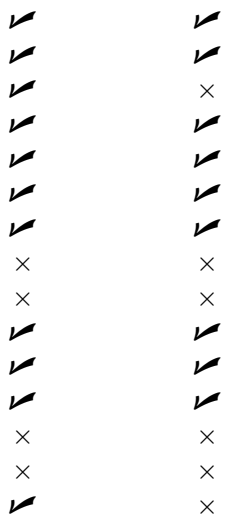

for applicable, and $\times$ for non-applicable.

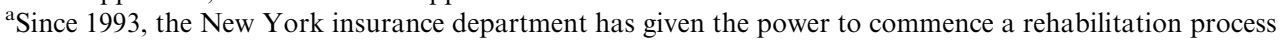
when a life, accident or health insurance firm fails to meet an "an authorized control" or a "mandatory control level" risk-based capital requirement.

action or an order of suspension that requires a firm to cease the whole or part of its operations. The commissioner can place a request to court for an order of rehabilitation or liquidation. In California, the insurance commissioner may request a Superior Court's order of conservation (equivalent to rehabilitation in New York) or liquidation. Liquidation commonly occurs after conservation.

\section{Summary of observations}

Discussed in this paper are regulations governing market exits in insurance markets, and conflicts arising from differences in firm-specific objectives and a public policy objective. The findings from examining laws and regulations in Asia, Europe, and North America show that regulators share three fundamental objectives. First, they emphasize the protection of the rights of the policyholders and insurance claimants. Various forms of regulation, which tend to be stringent, evidence this importance.

Second, regulators are gatekeepers, controlling whether and how insurance firms can exit the market. Regulators are an inseparable part in every exit process and monitor the process until completion, whether the exit is voluntary or involuntary, whether it is through a transfer of liabilities to another firm or an immediate dissolution, or whether it is a case of merger or acquisition.

Finally, of the firms that have traversed the insolvency threshold set by the law, only a few have been subject to immediate liquidation of assets and dissolution of business. Regulators often assist them in drawing a rehabilitation plan and in implementing it 
under a close supervision of the authority or its designee. Instead of simple dissolution of business, regulators tend to prefer a voluntary transfer of insurance obligations to another insurance firm, a regulator-arranged transfer, a merger, or an acquisition by another insurance firm. Their preference is more obvious in the case of insolvency of life insurance firms. It is expected that a successful rehabilitation of a firm, or transfer of its liabilities to another, translates into a reduced disruption in the insurance market.

Not all countries examined, however, have transparent regulatory guidelines. For example, the law of China simply states that the authority may create a liquidation task force to administer matters related to division, merger, and dissolution of an insurance firm but stops short of elaborating the scope of authority and duty of the task force. Hong Kong, which has a developed insurance market with dozens of insurance firms, still permits a group of 10 policyholders to file a bankruptcy petition to the court. A Pakistani court may order a reduction of insurance benefits that an insolvent firm is liable for to its policyholders. Insurance laws in several other countries (e.g., the United Arab Emirates and Iran) fail to elaborate on material matters related to insurer exits from the market.

Like entry regulation, exit regulation plays an important role in the insurance market. When the government has in place well-defined guidelines about the permitted form(s) of exit from the market as well as the expected cost of market exit, it can attract more insurance firms to the market. Presence of such guidelines, however, does not explain fully why firms choose a certain exit strategy. A conflict of objectives between the regulator and a firm wishing to exit a market may affect the choice. Prevailing internal and external factors of each firm can also affect the choice. The relationship between these factors and the response of firms to a given set of exit choices can be tested empirically. The authors will offer in a separate paper findings from an empirical examination of, among other, firm characteristics affecting exit strategies of insurance firms.

\section{References}

Association of Run-off Companies (2003) 'The Size and Growth of the Run-off Market', http:// www.arcrunoff.com, accessed June 24.

Bain, J. (1956) Barriers to New Competition, Cambridge: Harvard University Press.

Basel Committee on Banking Supervision (2003) Overview of the New Basel Capital Accord, Basel: Bank for International Settlements.

BarNiv, R. and Hathorn, J. (1997) 'The Merger or Insolvency Alternative in the Insurance Industry', Journal of Risk and Insurance 64: 89-113.

Baumol, W., Panzar, J. and Willig, R. (1982) Contestable Markets and the Theory of Industry Structure, New York: Harcourt, Brace, Jovanovich.

Bedell, D. (2003) Successful Exit Strategies for the Insurance Industry, London: Reactions.

Bernheim, D. (1984) 'Strategic Entry Deterrence of Sequential Entry into an Industry', Rand Journal of Economics 15: 1-11.

Boddewyn, J. (1983) 'Foreign and domestic divestment and investment decisions: Like or unlike?' Journal of International Business Studies 14: 23-35.

Consolidated Insurance Business Act of 2003, Denmark.

Directive 2001/17/EC of the European Union and of the Council on the Reorganization and Winding-up of Insurance Undertakings (March 19). 
Dunham, W. and Warrick, L. (2003) 'Rehabilitation, Liquidation and Insolvency', in W. Dunham (ed.) New York Law, New York: Matthew Binder.

Eger, T. (2001) 'Bankruptcy Regulations and the New German Insolvency Law from an Economic Point of View', European Journal of Law and Economics 11: 29-46.

Europe Economics (2004) Study on Irish Non-life Insurance with particular reference to Motor Insurance, Employer's Liability and Public Liability Insurance, (February 16) London: Europe Economics.

European Commission Solvency Subcommittee (2002) Considerations on the design of a failure of prudential supervisory system, a paper for the Solvency Subcommittee, European Commission: Brussels.

Federal Law (Insurance) No. 9 of 1984 United Arab Emirates.

General Insurance Association of Japan (2003) Fact Book 2002-2003, General Insurance in Japan, Tokyo: General Insurance Association of Japan.

IMF (2000) 'Insurance supervision', in Report on the Observance of Standards and Codes: Canada, Washington, DC: International Monetary Fund, (http://www.imf.org/external/np/rosc/can/insurance.htm).

Insurance Law of the People's Republic of China of 2003.

International Association of Insurance Supervisors (IAIS) (2003) Insurance Core Principles and Methodology, Basel: IAIS.

Insurance Act of 1995, Austria.

Insurance Act of 1996 (Amended in 1999), Malaysia.

Insurance Act of 2000 (Amended in 2003), Singapore.

Insurance Companies Act of 1991, Canada.

Iranian Insurance Act, (partially translated by www.haminoor.com).

Ilmakunnas, P. and Topi, J. (1999) 'Microeconomic and macroeconomic influences on entry and exit of firms', Review of Industrial Organization 15: 283-301.

Japan Insurance Business Law (1996) translated by Mizuho Securities.

Jensen, M. and Meckling, W.E. (1976) 'Theory of the firm: Managerial behavior, agency costs, and ownership structure', Journal of Financial Economics 3: 305-360.

Law of Insurance Companies, Slovenia.

Life Insurance Act (1992), Thailand.

Karakaya, F. (2000) 'Market exit and barriers to exit: Theory and practice', Psychology \& Marketing 17: 651-668.

KPMG International (2003) The U.K. Run-off Survey, (November), London: KPMG

KPMG International (2004) The U.K. Life Run-off Survey, London: KPMG.

Macau Insurance Companies Ordinance of 1997.

Matthyssens, P. and Pauwels, P. (2000) 'Uncovering International Market-Exit Process: A Comparative Case Study', Psychology \& Marketing 17: 697-719.

Nees, D. (1981) 'Increase your divestment effectiveness', Strategic Management Journal 2: 119-130.

Nonlife Insurance Act of Thailand (1992).

Norway Act on Insurance Activity (2001).

Peach, N. (1998) 'Contestability reconsidered: The meaning of market exist costs', Journal of Economic Behavior and Organization 34: 434-443.

Resnick, L. (1998) 'Making the tough decision: Hold or fold', National Underwriter 102: 15-22.

\section{About the Authors}

W. Jean Kwon, Ph.D., CPCU, is an associate professor of insurance at the School of Risk Management of St. John's University, New York, U.S.A.

Hunsoo Kim, Ph.D., is an associate professor with SoonChunHyang University in Korea.

Soon-Jae Lee, Ph.D., is an associate professor of insurance with Sejong University in Korea. 